\title{
Hour Times Microgram Per Milliliter Per Milligram Per Gram Per Day
}

National Cancer Institute

\section{Source}

National Cancer Institute. Hour Times Microgram Per Milliliter Per Milligram Per Gram

Per Day. NCl Thesaurus. Code C117935.

Hour times microgram per milliliter, divided by milligram per gram per day. 